\title{
The Relationship Between Depression and Sexual Function in Individuals with Chronic Obstructive Pulmonary Disease
}

\author{
Nuran Dudaklı' (D, Mualla Yılmaz² (1) \\ 'Psychiatric Clinic, Mersin City Training and Research Hospital, Mersin, Turkey \\ 2Department of Mental Health Nursing, Mersin University Nursing Faculty, Mersin, Turkey
}

ORCID iDs of the authors: N.D. 0000-0003-4050-4636; M.Y. 0000-0003-2685-4306.

Cite this article as: Dudaklı N, Yılmaz M. The Relationship Between Depression and Sexual Function in Individuals with Chronic Obstructive Pulmonary Disease. Cyprus J Med Sci 202I; 6(I): 24-9.

\section{BACKGROUND/AIMS}

It is important to determine the relationship between depression and the sexual functions of individuals with chronic obstructive pulmonary disease (COPD).

\section{MATERIAL and METHODS}

This research is a descriptive, cross-sectional, correlational study that consisted of 104 patients with COPD who were referred to the Chest Diseases Polyclinic of the Medical Faculty Hospital of one university between October 2016 and April 2017. The data of the study were collected using 3 data collection tools: the Personal Information Form, the Beck Depression Inventory (BDI), and the Arizona Sexual Experiences Scale (ASEX).

\section{RESULTS}

The results show that $20.2 \%$ of patients with COPD had severe depression. Furthermore, women with chronic obstructive lung disease were found to have more sexual problems than men, and men were found to have higher depressive symptoms than women. There was a positive, lower rate $(r=0.388)$, significant relationship $(p<.00 I)$ between the ASEX total score and the BDI total score. According to this result, as depression levels of individuals with COPD increase, their sexual problems also increase.

\section{CONCLUSION}

It is suggested that training programs for the prevention and treatment of depression and sexual dysfunction in individuals with COPD should be implemented and that psychiatric nurses and consultation-liaison psychiatric nurses should take an active role in these trainings.

Keywords: Chronic obstructive pulmonary disease, depression, sexuality

\section{INTRODUCTION}

Respiratory system diseases are among the diseases that cause serious health problems worldwide (I). Chronic obstructive pulmonary disease (COPD) is a progressive, life-threatening disease with no curative treatment resulting in airflow restriction, which can lead to complete loss of irreversible lung function (2).

The Global Burden of Disease study reported a prevalence of 251 million cases of COPD globally in 20l6 (3). In a study conducted in our country, the prevalence of COPD based on clinical diagnosis and spirometry is $4 \%$ (4). In a pilot study, COPD prevalence in individuals aged $>40$ years was reported to be around $20 \%$ (5). There are many factors that cause COPD (6). These factors are divided into 2 groups: environmental factors and genetic factors. Chemical substances, household dust, smoking, infection, and negative socioeconomic conditions are among the causes of COPD. The most important risk factor for COPD is smoking $(5,7,8)$. Lifelong smokers have a $40-50 \%$ of developing COPD, and nonsmokers have a 10\% probability of developing COPD during their lifetime. In addition, exposure to dust chemical fumes, vapors, or other harmful gases in the atmosphere can also cause COPD (9).

COPD is most common in people aged at least 35 or $\geq 40$ years, and the disease can develop at these ages (I0). The Turkish Thoracic Society reports that COPD occurs at the age of $\geq 40$ years (II). However, individuals usually present to the health institution at around age 50 years (12). 
In our country, treatment and care programs for the development of lung function are also identified while planning the care and treatment of individuals with COPD, but depression and sexual functioning that reduce the quality of life are ignored (I3). In one study, $51.5 \%$ of the individuals with COPD who were assessed with the Beck Depression Scale received a score that was consistent with moderate or severe depression (14).

The prevalence of depression was $27.1 \%$ in patients with COPD and $10 \%$ in the control group (15). Studies have shown that about $40 \%$ of individuals with COPD are affected by severe depressive symptoms or clinical depression (16), that the rate of depression accompanying COPD is $44 \%$ (17), that the prevalence of depression is $72 \%$ (18), and that the rate of depression seen in those with chronic respiratory disease is $70 \%$ (19).

Symptoms of COPD, such as breathlessness, coughing, and sputum, have a negative effect on sexuality in both sex and may lead to loss of self-confidence and lack of attractiveness in the sexuality process. Fear and anxiety of dyspnea decrease sexual interest and pleasure. Morale disorders, such as depression, which is an important problem for patients with COPD, also have effects on sexual interest and function (20). In addition, some drugs used in the treatment of respiratory system diseases (bronchodilator) cause mental problems, such as depression, in individuals (21). In a study, $67.7 \%$ of erectile dysfunction was found in patients with COPD (22).

Ibanez et al. (23) reported that there was a relationship between lung function and sexual problems in a study that stated that spouses of those patients were less satisfied with sexual intercourse caused by noncommunication. In their study with women diagnosed with COPD in the age range of 30-40 years, Abd-Elsalam et al. (24). reported that the cases affecting sexual intercourse were caused by $91.9 \%$ difficulty in breathing, 62\% breathlessness, 54\% fatigue, $97.6 \%$ specific sex positions, $96.9 \%$ decreased sexual performance.

Whereas patients experience many problems related to depression and sexual life owing to the disease, they often cannot find an environment where they can express their problems. Patients should learn to live with COPD, a chronic disease. In this learning process, nurses have important responsibilities. The nurses who work with the patient 24 hours should provide nursing care to the patient with a holistic perspective in terms of biopsychosocial perspective in the process of patient's acceptance of the disease, learning to live with the disease, and adaptation and rehabilitation process. In addition, this paper is crucial because it is aimed to determine the relationship between depression and sexual functions in patients. Identifying and revealing this relationship will contribute to the field of nursing science.

\section{Main Points:}

- Individuals with COPD in Turkey had severe depression.

- Women with chronic obstructive lung disease had more sexual problems than men.

- Men with chronic obstructive lung disease had higher depressive symptoms than women.

- As depression levels of individuals with COPD increase, their sexual problems also increase.
There is a scarcity of studies that investigates the relationship between depression and sexual function of patients diagnosed with COPD in the world and in our country. This study is aimed to determine the relationship between the sexual life and depression symptom levels of individuals with COPD.

In this study, the following questions were asked:

I. What is the depression level of individuals with chronic obstructive pulmonary disease?

2. Is there any sexual dysfunction in individuals with chronic obstructive pulmonary diseases?

3. Is there a relationship between depression and the sexual functions of individuals with chronic obstructive pulmonary disease?

\section{MATERIAL and METHODS}

This study is a descriptive, cross-sectional, correlational study. A total of 208 patients diagnosed with COPD at a university hospital in Mersin, Turkey between October I, 2016 and April 20, 2017 were included in the study. Of the 208 patients in Mersin, 104 patients met the inclusion criteria. So, the response rate was $50 \%$. The inclusion criteria were individuals aged $\geq 40$ years who had been diagnosed with COPD for at least 6 months, individuals who had active sexual life, and individuals who volunteered to participate in the study. The study was conducted with 104 patients diagnosed with COPD.

\section{Data Collection}

Data were collected using 3 data collection tools: Personal Information Form, the Beck Depression Inventory (BDI), and the Arizona Sexual Experiences Scale (ASEX). Data were collected in an empty room on the polyclinic floor and for approximately 20 minutes for each patient.

\section{Data Collection Tools}

Personal Information Form. The personal information form consists of 15 questions based on the literature $(7,8,25-27)$ and includes information, such as the patient's age, sex, occupation, marital status, educational status, income status, health insurance, and sociodemographic characteristics.

BDI. BDI was developed by Beck. The BDI includes 21 items for qualifying the levels of depression. The Turkish validity and reliability of the BDI were studied by Nesrin Hisli (28). The BDI is scored from 0 to 3 for each question. Low scores indicate minimal depression, and higher scores indicate severe depression. The lowest score is 0 , the highest possible total score for the whole test is 63. According to the BDI table, the scores of I-I0 indicate no depression, scores of $\mathrm{II}-\mathrm{I6}$ indicate mild mood disturbance, scores of 17-20 indicate borderline clinical depression, scores of 21-30 indicate moderate depression, scores of 31-40 indicate severe depression, and scores of 4I-63 indicate extreme depression. The Cronbach alpha coefficient of reliability is $0.86 .^{28}$ In this study, the alpha coefficient of reliability was found to be 0.88 .

ASEX. ASEX is used to evaluate the 5 main components of sexval function. These are arousal, desire, penile erection or vaginal lubrication, orgasm, and satisfaction. The question about penile erection and vaginal lubrication can be different in the male and female versions of ASEX. This Likert-type scale consists of 
5 questions. Because there are 5 questions and each is scored from I to 6 , the total score is from 5 to 30 . Turkish validity and reliability of the scale were assessed by Atilla Soykan (29) in 2002. This scale cut-off point is $\geq 1$ scale score point.

The Cronbach alpha value of the scale was found to be 0.89 and 0.90 . A total score of $\geq 11, \geq 5$ on any item, $\geq 4$ on 3 items indicate sexual dysfunction and is highly correlated with clinician-defined sexual dysfunctions (29). The Cronbach alpha coefficient of reliability for the sample in this study was found to be 0.90 .

\section{Statistical Analysis}

The normal distribution of the data was tested with the Kolmogorov-Smirnov test, and the data were found to have a normal distribution. Frequencies and percentages were calculated for categorical variables, whereas descriptive statistics (minimum and maximum values and mean and standard deviation) were calculated for continuous variables. Independent $t$-test and I-way analysis of variance were used to analyze the data. Tukey post-hoc test was applied to determine which variables were significant for the significant values in groups of more than 2. A chi-square test was used to calculate the relationship between the categorical variables. Pearson correlation test was used to test the relationship between the total scores of the scale. Cronbach's alpha coefficient was calculated to test the reliability of the questionnaire. The results were evaluated with a $95 \%$ confidence level at $P \leq .05$ significant level.

\section{Ethical Approval}

Ethics committee permission was received from the Clinical Research Ethics Committee of one university (06/10/2016, number: 228266), and institution permission was also obtained from the medical faculty and application center of one university. Written and oral informed consent was obtained from all patients included in the study. Data collection was completed by having patients in Chest Diseases Clinic fill the forms mentioned earlier, paying attention to the patients' privacy. The patients were informed that their information would be kept confidential and that they were free to stop participating in the research at any time.

\section{RESULTS}

A total of $57.7 \%$ of the participants were male, the age range was $40-88$ years, and the mean age was $58.2 \pm+11.2$ years. A total of $84.6 \%$ of the individuals with COPD were married, $57.7 \%$ were primary school graduates, $26.9 \%$ were housewives, $25.0 \%$ were retired, $88.5 \%$ had social security, $42 \%$ had a balanced income status, and $43.3 \%$ were living together with their spouse and children. The disease duration of individuals with COPD was between 6.5 and 360 months, and the mean duration was $81.4 \pm 72.5$. A total of $57.7 \%$ of the individuals with COPD stopped smoking, and $23.1 \%$ continued to smoke. When COPD stages were examined, it was found that $50.0 \%$ of the individuals were in the first or mild stage, $96.2 \%$ had shortness of breath, and $82.7 \%$ had a cough and wheezing.

As presented in Table I, $21.2 \%$ of individuals with COPD had ups and downs in their mental status, and they also had normal and moderate mood disorders. In addition, it was determined that $20.2 \%$ of individuals with COPD had severe depression. A total of $57.6 \%$ of individuals with COPD had a score of $\geq 17$, and clinical treatment was determined to be necessary (Table I).
When the ASEX average scores of the individuals with COPD were examined, ASEX total scores of women (19.1 \pm 7.8$)$ were found to be higher than those of men $(15.9 \pm 4.7)$. The average ASEX score was $17.3 \pm 6.4$ (Table 2).

Table 3 shows the BDI total scale scores of individuals with COPD and the relationship between age and disease duration. There was a positive mild relationship between the total scores of the ASEX and the BDI total score $(r=0.388)$, and this relationship was significant $(p<.00 \mathrm{I})$. According to this result, it can be inferred that as the depression levels of individuals with COPD increase, their sexual dysfunction also increases. There was a positive, moderate, and statistically significant relationship between age and the total score of the ASEX $(r=0.415 ; p<.001)$. Ac-

\begin{tabular}{|c|c|c|}
\hline BDI & $\mathrm{n}$ & $\%$ \\
\hline I-10: The ups and downs in mental status are normal & 22 & 21,2 \\
\hline II-16: Moderate mood disorders & 22 & 21,2 \\
\hline 17-20: Borderline clinical depression & 12 & 11,5 \\
\hline 21-30: Moderate depression & 20 & 19,2 \\
\hline 31-40: Severe depression & 21 & 20,2 \\
\hline 41-63: Severe depression & 7 & 6,7 \\
\hline
\end{tabular}

TABLE 2. ASEX Average Scores of Individuals with COPD $(n=104)$

\begin{tabular}{lccc|} 
ASEX & $\mathbf{n}$ & Mean \pm SD & $\begin{array}{c}\text { Lower and } \\
\text { upper values }\end{array}$ \\
\hline Sexual desire & 104 & $3.5 \pm 1.6$ & $1-6$ \\
Sexual arousal & 104 & $3.3 \pm 1.5$ & $1-6$ \\
Penile erection/vaginal lubrication & 104 & $3.6 \pm 1.4$ & $1-6$ \\
Sexual orgasm & 104 & $3.4 \pm 1.5$ & $1-6$ \\
Sexual satisfaction & 104 & $3.5 \pm 1.4$ & $1-6$ \\
ASEX (female) & 44 & $19.1 \pm 7.8$ & $6-30$ \\
ASEX (male) & 60 & $15.9 \pm 4.7$ & $7-30$ \\
Total scale score of the ASEX & 104 & $17.3 \pm 6.4$ & $6-30$ \\
\hline $\begin{array}{l}\text { ASEX: Arizona Sexual Experiences Scale, COPD: chronic obstructive } \\
\text { pulmonary disease. }\end{array}$ & \multicolumn{4}{l}{} \\
\hline
\end{tabular}

TABLE 3. The Relationship BDI and ASEX With Age and Disease

Duration of the Individuals with Chronic Obstructive Pulmonary

Disease

Correlation Between BDI, ASEX,

Age and Disease Duration

ASEX

BDI

$\mathrm{BDI}$

0.388

$\begin{array}{lccc} & P & \left.0.00\right|^{* *} & \\ \text { Age } & r & 0.415 & 0.287 \\ \text { Disease Duration } & P & <.001^{* *} & 0.003^{*} \\ & r & 0.133 & 0.168 \\ & P & 0.177 & 0.089\end{array}$

${ }^{*} p<.0 \mathrm{Ol},{ }^{*} p<.00 \mathrm{I}$. ASEX: Arizona Sexual Experiences Scale, BDI: Beck Depression on 
cording to this result, it can be said that individuals with COPD have increased sexual dysfunction as their ages increase. There was a statistically significant positive and mild relationship between age and BDI total score $(r=0.287 ; p=.003)$. According to this result, it can be inferred that as the ages of individuals with COPD increase, their depression levels also increase. The relationship between COPD duration and the total score of ASEX was positive, mild, and not statistically significant $(r=0.133 ; p=.17)$. The relationship between COPD duration and BDI total score was not positive, was weak, and was statistically significant $(r=0.167 ; p=.089)$ (Table 3).

\section{DISCUSSION}

This study was conducted to determine the relationship between depression and the sexual functions of individuals with COPD. It was found that $70.2 \%$ of the individuals diagnosed with COPD were in the age range of 40-64 years, and the average age was $52.8 \pm 8.0$ years. More than half of the individuals were primary school graduates. Although COPD varies from country to country, it is a serious public health problem that threatens $10-15 \%$ of the population aged $>40$ years (2). In a pilot study, the prevalence of COPD in individuals aged $>40$ years was found to be around $20 \%$ (5). It is stated in the literature that the age of diagnosis of COPD is $\geq 40$ years $(10,11)$. In this study, the average age of individuals with COPD is 52.8 years, similar to that reported in the literature. In a study by Castelino et al. (30), it was found that $13.6 \%$ of individuals with COPD were not literate and that $43.6 \%$ were primary school graduates.

In this study, we found that more than half of the individuals with COPD experienced depression and that depression treatment was clinically required. Studies have shown that about $40 \%$ of individuals with COPD are affected by severe depressive symptoms or clinical depression (16), that the rate of depression accompanying COPD is $44 \%$ (17), that the prevalence of depression is $72 \%$ (18), and that the rate of depression seen in those with chronic respiratory disease is $70 \%$ (19). Our study is in parallel with the literature. For depression

levels, it is thought that COPD is a chronic disease that negatively affects the quality of life and that the prevalence of depression is high in the patients owing to their reactions to the disease and owing to the limitations and barriers caused by the disease. In this study, it was found that women experienced more sexual problems than men and that nearly all individuals with COPD (96.2\%) experienced shortness of breath. A study by Ayoade et al. (3I) reported that age and gender affected sexual performance, and Kaptein et al. (32) also reported that women had more difficulty in breathing during sexual intercourse than men. Ibanez et al. (23) reported a relationship between lung function and sexual problems in a study conducted on only male patients, and they also stated that spouses of those patients were less satisfied with sexual intercourse caused by noncommunication. In their study with women diagnosed with COPD in the age range of 30-40 years, Abd-Elsalam et al. reported that the cases affecting sexual intercourse were $91.9 \%$ caused by difficulty in breathing, $62 \%$ caused by breathlessness, $54 \%$ caused by fatigue, $97.6 \%$ caused by specific sex positions, and $96.9 \%$ caused by decreased sexual performance (24). The findings of this study are in parallel with the literature. Many beliefs about sexuality are exaggerated. These beliefs are often nonobjective and false. Individuals often show these beliefs in the daily press and pornographic publications by telling jokes about sexuality. These beliefs mostly depreciate and devalue women. There is a wrong belief in society that sexuality is only for men and that women should not have sex (33). It is thought that women avoid expressing their sexual problems and accepting consultations with physicians.

In this study, it was determined that the most common sexual problem was in vaginal lubrication/penile erection, followed by sexual desire, satisfaction, orgasm, and sexual arousal problems. Kahraman et al. (I3) reported that the rate of erectile dysfunction was $78.6 \%$ in patients with COPD, and the severity and frequency of erectile dysfunction were higher in patients with COPD than in the control group. In their study of individuals with COPD, they stated that $78.9 \%$ of the patients had decreased sexual desire, and $76.3 \%$ had decreased the sexual intercourse (34). Yacan and Erol reported that there were fewer orgasms in cases of chronic complications (35).

In this study, we found that women with COPD had higher scores on COPD total scale scores than men in terms of sexual desire, sexual arousal, and orgasm. Levack stated that COPD predisposes women to fewer sexual problems than it does to men. He stated that men's sexual activity is more dependent on health than women's sexual activity, that having a sexually satisfying husband and a pleasurable sexual experience is more important for women, and that men are more vulnerable to lose their self-confidence and have difficulty in breathing owing to reduced sexual performance (36). This finding differs from our study. In our country, girls are taught not to be interested in sexuality while they are raised. The traditional female role is associated with a number of beliefs, such as women should control their emotions about sexvality (33). It is thought that women adopt this social role, have low education levels, and do not know how to cope with these social judgments, and because of these reasons, women develop sexual, sexual arousal, orgasm problems.

In this study, there was a positive, low, and significant relationship between the total scores of ASEX and BDI total score. According to this result, it can be inferred that as the depression levels of individuals with COPD increase, their sexual dysfunction also increases. In a randomized controlled study, the prevalence of sexual dysfunction in patients with depression was twice as high as that in the control group (50\% vs 24\%) (37). Reynaert et al. (38) reported that there was a strong association between depression and sexual dysfunctions and also that certain antidepressants had adverse effects on sexual function. Akyol et al. (39) have reported that sexual dysfunctions are more common in patients with high anxiety and depression scores. There is a widespread consensus that patients with depression have a higher rate of sexual dysfunction than the general population $(7,10)$. Karson et al. stated that lack of penile erection, the reason for sexual reluctance, and vaginismus were largely due to depression, and the pre-ejaculation was definitely due to depression. They also reported that sexual reluctance is mostly attributed to hormonal causes, but almost all of the causes are depression (40). In a study by Alacacıoğlu et al. (4I), the scores of communication, satisfaction, avoidance, pre-ejaculation, and erectile dysfunction were higher in individuals with high depression scores than in individuals with low depression scores. 
In this study, it was determined that patients with COPD had sexual problems and that there was a relationship between their sexual problems and their depression levels. Patients with COPD who have sexual problems (women, those with inadequate income, those with low levels of education, housewives) should be regularly followed up by nurses, evaluating their mental status and organizing regular training programs about the management of the disease and mental and sexual problems; training conducted through press and media programs is also recommended. It can be argued that nurses should be aware of the patient's sexual lifestyle and functioning. These patients should be referred to comprehensive sexual health programs for treatment, if available.

This study was conducted on patients in a single university hospital, and this was accepted as a limitation. The limitations of this study include a small sample size and recruitment from a single center. During the period in which the study was conducted, only 104 of 208 patients undergoing peritoneal dialysis treatment elected to participate in the study.

Ethics Committee Approval: Ethics committee approval was received for this study from the ethics committee of Mersin University (Approval Date: 06/10/2016, Approval Number: 228266).

Informed Consent: Written and oral informed consent was obtained from all patients included in the study.

Peer-review: Externally peer-reviewed.

Author contributions: Concept - M.Y., N.D.; Design - N.D.; Supervision M.Y.; Resource - N.D.; Materials - N.D.; Data Collection and/or Processing - N.D.; Analysis and/or Interpretation - N.D., M.Y.; Literature Search - N.D., M.Y.; Writing - N.D., M.Y.; Critical Reviews - M.Y.

Conflict of Interest: Authors have no conflicts of interest to declare.

Financial Disclosure: The authors declared that they have received no financial support for this study.

\section{REFERENCES}

I. Marciniuk D, Nana A, Blasi F, Kraft M, Mondes De Oca M, Carter EJ, et al. Respiratory Diseases In The World Realities of Today-Opportunities For Tomorrow. African Journal of Respiratory Medicine 2014; 9(I): 4-13.

2. Süerdem M. KOAH. Pharmaword 20I6; 6(15): 63-6.

3. World Health Organization (WHO). Chronic Obstructive Pulmonary Disease (COPD) 2019. Available From: https://www.who.int/newsroom/fact-sheets/detail/chronic-obstructive-pulmonary-disease-(copd) (cited 2019 July 28.

4. Kocabaș A, Atıș S, Çöplü L, Erdinç E, Ergan B, Gürgün A, et al. Kronik Obstrüktif Akciğer Hastalığı (KOAH) Koruma, Tanı ve Tedavi Raporu. Türk Toraks Dergisi 2014; (2): I-II.

5. Umut S. Kronik Obstrüktif Akciğer Hastalığında Atak. Toplumdan Edinilmiș Enfeksiyonlara Pratik Yaklașımlar Sempozyum Dizisi 2008; 61: 117-28.

6. European Lung Foundation (ELF). Living Well With COPD 2017. Available From: http://www.europeanlung.org/assets/files/en/ publications/living-well-with-copd.pdf (cited 2019 Apr 30).

7. Umut S, Erdinç E. Kronik Obstrüktif Akciğer Hastalığı (KOAH) ile Yașam. Ankara, Turkey: Anıl Reklam Matbacılık; 20II.

8. Karadağ M. KOAH Tedavisinde Sigaranın Bıraktırılması. Güncel Göğüs Hastalıkları Serisi 20।3; I(I): 98-I04.

9. COPD (2013). Available From: http://www.europeanlung.org/assets/files/en/infographics/copd.pdf (cited 2019 Apr 30).
10. Alșan Y. Kronik Obstrüktif Akciğer Hastalığı (KOAH) Üzerine Klinik Yol Çalıșması: Bașkent Üniversitesi Hastanesi'nde Bir Uygulama (Yüksek Lisans Tezi). Ankara: Bașkent Üniversitesi Sosyal Bilimler Enstitüsü 2009.

II. Kronik Obstrüktif Akciğer Hastalığı (KOAH) (2017). Available From: http://www.toraks.org.tr/halk/Page.aspx?d=10 (cited 2019 Apr 30).

12. Köktürk N, Arsava BE, Ergün P, Kılınç O, Öztürk D, Yıldıran H. Kronik Obstrüktif Akciğer Hastalığı (KOAH). Erdinç M, Gülmez i. (eds). Turkey: Ankara; Sentez Yayınclık; 2013: 7.

13. Kahraman H, Sen B, Koksal N, Kilinç M, Resim S. Erectile Dysfunction and Sex Hormone Changes in Chronic Obstructive Pulmonary Disease Patients. Multidisciplinary Respiratory Medicine 20I3; 8(I): 66. [Crossref]

14. Miravitlles M, Molina J, Quintano JA, Campuzano A, Perez J, Roncero $\mathrm{C}$, et al. Factors Associated With Depression and Severe Depression in Patients With COPD. Respiratory Medicine 20I4; 108(II): 1615-25. [Crossref]

15. Matte DL, Pizzichini MMM, Hoepers ATC, Diaz AP, Karloh M, Dias $M$, et al. Prevalence of Depression in COPD: A Systematic Review and Metaanalysis of Controlled Studies. Respiratory Medicine 2016; II7: 154-61. [Crossref]

16. Stage KB, Middelboe T, Stage TB, Sørensen CH. Depression in COPD- Management and Quality of Life Considerations. International Journal of COPD 2006; I(3): 315-20. [Crossref]

17. Kaneda R, Snjyu H, Iguchi A, Hayashi Y, Iwai S, Tsuda T, et al. Factors That Impact Anxiety and Depression in Patients With Chronic Obstructive Pulmonary Disease. J Phys Ther Sci 20ll; 23(6): 927-31. [Crossref]

18. De S. Prevalence of Depression in Stable Chronic Obstructive Pulmonary Disease. Indian J Chest Dis Allied Sci 20ll; 53: 35-9.

19. Aydemir Y, Doğu Ö, Amasya A, Yazgan B, Ölmez Gazioğlu E, Gündüz H. Kronik Solunum ve Kalp Hastalıklarında Anksiyete ve Depresyon Sıklığı ve Illișkili Özelliklerin Değerlendirilmesi. Sakarya Med J 2015; 5(4): 199-203. [Crossref]

20. Levack WMM, Poot B, Weatherall $M$, Travers J. Interventions for Sexual Dysfunction in People with Chronic Obstructive Pulmonary Disease (COPD) (Review). Cochrane Airways Group (ed). New Zealand: Otago, Published by John Wiley a Sons; 2014: I-28. [Crossref]

21. Özdemir Ü, Tașçı S. Kronik Hastalıklarda Psikososyal Sorunlar ve Bakım. Erciyes Üniversitesi Sağlık Bilimleri Fakültesi Dergisi 20।3; I(I).

22. Turan $\mathrm{O}$, Ure I, Turan PA. Erectile dysfunction in COPD patients Chronic Respiratory Disease 2016; 13(I): 5-12. [Crossref]

23. Ibanez M, Aguilar JJ, Maderal MA, Prats E, Farrero E, Font A. Sexuality in Chronic Respiratory Failure: Coincidences and Divergences Between Patient and Primary Caregiver. Respir Med 2001; 95(12): 975-9. [Crossref]

24. Abd-Elsalam FG, Mahgoub NA, Ghoneim AH, Abou-Abdu SE. Chronic Obstructive Pulmonary Disease and Sexual Functioning Among Women in Egypt. Egyptian Journal of Chest Diseases and Tuberculosis 2015; 64: 55I-6. [Crossref]

25. Öztürk O. Ruh Sağlığı ve Hastalıkları. Ankara, Turkey: Baył yayınları, Tuna Matbaacilık; 2015: 26I-355.

26. Çevirme L. Kronik Obstrüktif Akciğer Hastalığı Olan Olgularda Solunum Fonksiyonlarının, Yașam Kalitesinin, Anksiyetenin ve Depresyonun Alevlenme Sayısına Ełkisi (Yüksek Lisans Tezi). Edirne: Trakya Üniversitesi Tıp Fakültesi Göğüs Hastalıkları Anabilim Dalı 2008.

27. Yılmaz A, Göker C, Koçak OM, Aygör B, Șentürk V, Nergizoğlu G, et al. Hemodiyaliz Hastaları ve Eșlerinde Cinsel İșlev: Türkiye'den Prospektif Bir Çalıșmanın Sonuçları. Turk J Med Sci 2009; 39(3): 405-14.

28. Hisli N. Beck depresyon Envanterinin Geçerliği Üzerine Bir Çalıșma. Psikoloji Dergisi 1988; 6(22): II8-26.

29. Soykan A. The Reliability And Validity Of Arizona Sexual Experiences Scale In Turkish ESRD Patients Undergoing Hemodialysis. International Journal of Impotence Research 2004; 16(6): 53I-4. [Crossref] 
30. Castelino F, Prabhu M, Pai MS, Kamath A, Mohapatra AK, Devi ES, et al. Socio-Demographic And Clinical Characteristics Of Chronic Obstructive Pulmonary Disease (COPD) Patients. Manipal Journal of Nursingand Health Sciences 2017; 3(2): 55-8.

31. Ayoade OT, Blavo FJ, Farotimi AA, Nwozichi CU. Sociodemographic Factors As Predictors of Sexual Behavior of Secondary School Students In Lagos State, Nigeria. International Journal of Medicine and Public Health 2015; 5(2): 152-6. [Crossref]

32. Kaptein AA, Van Klink RCJ, Kok FD, Scharloo M, Snoei L, Broadbent E, et al. Sexuality in Patients With Asthma and COPD. Respiratory Medicine 2008; 102(2): 198-204. [Crossref]

33. Cinsel Eğitim Tedavi ve Araștırma Derneği (CETAD). Cinsel Yașam ve Sorunları 2017. Available From: http://www.cetad.org.tr/CetadData/Book/5/26920III5161I-bilgilendirme_dosyasi_l.pdf (cited 2019 Apr 30)

34. Ünsal A, Yetkin A. Kronik Obstruktif Akciğer Hastalığı Olan Bireylerin Günlük yașam Aktivitelerinin Ełkilenme Durumunun İncelenmesi. Atatürk Üniv. Hemșirelik Yüksekokulu Dergisi 2005; 8(I).

35. Yacan L, Erol O. Evaluation of Sexual Function Among Women Withor Without Diabetes. Sexuality and Disability 2018; 36. [Crossref]
36. Levack WMM. Sexual Wellbeing for People With Chronic Obstructive Pulmonary Disease: relevance and Roles for Physiotherapy. New Zealand Journal of Physiotherapy 2014; 42(2): $170-$ 6. [Crossref]

37. Doğan S. Cinsel İșlev Bozuklukları, Depresyon ve Antidepresanlar. Journal of Mood Disorders 20II; I(2): 8I-6.

38. Reynaert C, Zdanowicz N, Janne P. Jacques D. Depression and Sexvality. Psychiatria Danubina 20I0; 22(I): III-3.

39. Akyol M, Ülger E, Alacacioğlu A, Kucukzeybek Y, Yıldız Y, Bayoğlu V, et al. Sexual Satisfaction, Anxiety, Depression and Quality of Life Among Turkish Colorectal Cancer Patients (Izmir Oncology Group (IZOG) Study). Jpn J Clin Oncol 2015; 45(7): 657-64. [Crossref]

40. Karson F, Kocabıyık A, Eroğlu i. Çocuk ve Erișkinde Depresyon. İzmit, Turkey: Yașam Boyu İki Uçlu Duygudurum Derneği Klavuz Kitapçığı; 2016: 24.

4l. Alacacioğlu A, Ülger E, Varol U, Yıldız I, Salman T, Bayoğlu V, et al. Depression, Anxiety and Sexual Satisfaction in Breast Cancer Patients and Their Partners-izmir Oncology Group Study. Asian Pac J Cancer Prev 2014; 15(24): 10631-6. [Crossref] 